\title{
UNIVERSITY OF PENNSYLVANIA RADIOCARBON DATES XXII
}

\author{
BARBARA J HURST and BARBARA LAWN
}

Department of Physics and University Museum, University of Pennsylvania, Philadelphia, Pennsylvania 19104

\section{INTRODUCTION}

This date list includes most of the archaeologic and geologic samples dated in this laboratory since publication of our last date list (R, 1981, v 23, p 227-240), as well as some samples dated previously which lacked adequate sample information.

All samples were pretreated with $3 \mathrm{~N} \mathrm{HCl}$ and some, where noted, were given additional pretreatment with $2 \% \mathrm{NaOH}$ for the removal of possible humic acid contaminants.

The BP ages are relative to AD 1950, and have been calculated with the half-life value of 5568 yr using our mid-19th century AD calibration samples which have an average age of $145 \mathrm{yr}$. When corrected for this age, these calibration samples have ${ }^{14} \mathrm{C}$ contents equal to $95 \%$ of the NBS oxalic acid standard. $\delta^{13} \mathrm{C}$, where included, has been measured on this laboratory's Micromass 622 mass spectrometer, reported with respect to PDB, and the results corrected accordingly for isotopic fractionation. All samples were counted at least twice for periods of not less than $1000 \mathrm{~min}$ each. Errors quoted for each sample include the sum of the statistical counting uncertainties in the measurement of the sample, the background, and several counts of our mid-19th century AD oak sample, but do not include the possible half-life errors.

In addition to our two $8 \mathrm{~L}$ counters, a small $1 \mathrm{~L}$ counter is employed for counting undersized samples. Larger errors associated with these dates are a direct result of small sample size and consequently reduced number of counts. Use of the small counter is indicated by an asterisk $\left({ }^{*}\right)$ after the uncertainty of the BP date. In all counters we continue to use pure $\mathrm{CO}_{2}$.

The calibrated dates which appear in the sample comments are designated either as CRD-1 $\sigma$ or Stuiver corrected. $C R D-1 \sigma$ refers to BC era dates calibrated with tables based on the same data base and statistical methods as found in "Calibration of radiocarbon dates: tables based on the consensus data of the Workshop on Calibrating the Radiocarbon Time Scale" (R, v 24, p 103-150) but where the range represents a $67 \%$ confidence interval instead of $95 \%$ confidence interval (Jeffrey Klein, unpub). Stuiver corrected refers to AD era dates that have been calibrated using "A high-precision calibration of the AD radiocarbon time scale" ( $R$, $v 24, p$ 1-26). Both of the above-mentioned calibrations include the uncertainties assoc with the counting statistics of the sample and those assoc with the calibration itself. Where there is no calibrated date in an individual sample comment, it is because that date is beyond the range of currently available correction factors (BP 7230, 5568 half-life). For those readers interested in an age calculated with the 5730 year half-life, the given radiocarbon age should be multiplied by 1.029 . 


\title{
SAMPLE DESCRIPTIONS
}

\author{
ARCHAEOLOGIC SAMPLES
}

\section{Mediterranean}

Cyprus

\section{Kalavasos-Tenta series}

Kalavasos-Tenta, $2.25 \mathrm{~km}$ SSE of Kalavasos village, Larnaca Dist, Cyprus $\left(34^{\circ} 41^{\prime} \mathrm{N}, 33^{\circ} 18^{\prime} \mathrm{E}\right.$ ), is stratified habitation site representing both Aceramic and Ceramic Neolithic phases (Todd, 1978; 1982a,b). Coll and subm 1977 and 1978 by I A Todd, Dept Oriental Studies, Brandeis Univ, Waltham, Massachusetts. For previous dates from this site, see P-2458 to -2555 (R, v 20, p 218-219).

General Comment: except for P-2780 all samples are from Aceramic Neolithic contexts.

\section{P-2975. Sample K-T 21}

$6970 \pm 310^{*}$

Soil and charcoal from Sq F11 C, E baulk, deposit no. 2.5. Deposit lies outside any structures and is quite close to top soil (possibly disturbed by plough); dates Aceramic occupation of lower $\mathrm{S}$ face of site. Comment: CRD-10: 6335 to 5390 вC.

\section{P-2976. K-T 22}

$8870 \pm 500 *$

Soil and charcoal from $\mathrm{Sq} F 11 \mathrm{C}$, deposit no. 3.6, hearth outside structures and under caliche layer (from same basic area as P-2975, above, and est date probably similar).

P-2974. Sample K-T 10

$8020 \pm 90$

Mud and charcoal from Sq G9 D, deposit 3.6, dates occupation of mud-brick Structure 58, at top of site.

P-2977. Sample K-T 23

$6570 \pm 290 *$

Soil and charcoal from Sq G10 A, deposit no. 4.1, from pit that postdates and is dug into Structure 28 on top of site. Comment: CRD-1 $\sigma$ : 5830 to 5200 BC.

\section{P-2973. Sample K-T 19}

Soil and charcoal from Sq G10 A/G10 C; sample from Structure 34 (dates actual mudbrick structure or period immediately after).

P-2972. Sample K-T 18

Soil and charcoal from Sq G11 C, deposit no. 13.2/16.1; from one of earliest pits in lower $S$ area of site.

P-2781. Sample K-T 11

Charcoal from Sq G11 C, deposit no. 9.2, representing Aceramic Neo-

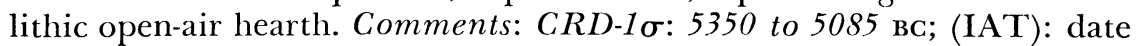
unexpectedly young; should be similar to P-2552, -2553 , and $-2555(\mathrm{R}$, 1978, v 20, p 218-219). 
P-2782. Sample K-T 12

$7600 \pm 100$

Charcoal from $\mathrm{Sq}$ G11 C, deposit no. 5.9, from Aceramic Neolithic open air area outside Structure 9; should be contemporaneous with P-2781 (above).

\section{P-2783. Sample K-T 13}

$7130 \pm 410 *$

Charcoal from Sq G11 C, deposit no. 5.5; Aceramic Neolithic openair Area E of Structure 9 and contemporaneous with it.

P-2784. Sample K-T 14

$7380 \pm 100$

Charcoal from Sq G12A, deposit no. 5.8.

P.2779. Sample K-T 9

$7120 \pm 90$

Charcoal from Sq G12 D, deposit no. 4.2; dates to early phase of stone

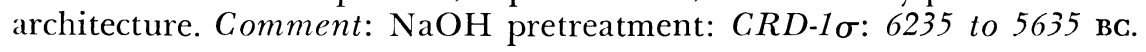

P-2785. Sample K-T 15

$8720 \pm 400$

Charcoal from Sq G12 D, deposit 5.1, from hearth (hollow cut in bedrock) $S$ of E end of Aceramic Neolithic Structure 1 (Dikaios' main wall).

P-2978. Sample K-T 24.

$\mathbf{7 4 0 0} \pm \mathbf{2 6 0}$

Soil and charcoal from Sq H12 A, deposit no. 2.4, open area, close to present ground surface in lower $S$ part of site and close to inner face of wall (probable outer wall of settlement's early phase).

\section{P-2780. Sample K-T 10}

$\mathbf{5 8 3 0} \pm \mathbf{6 0}$
$-27.5 \pm 0.3 \%$

Charcoal from Sq B7 C, deposit no. 2.4, Ceramic Neolithic deposit. Comments: CRD-10: 4755 to $4565 \mathrm{BC}$; (Frank Koucky): not archaeol in situ-deposited by water action.

P-2980. Kalavasos Village-Panayia Church, Sample $1 \quad 4330 \pm 80$

Charcoal found near Middle Bronze age vessel (no. 27), level $3 / 4$ in Tomb 2 at site $\mathrm{E}$ of Panayia Church, Kalavasos Village $\left(34^{\circ} 46^{\prime} \mathrm{N}, 33^{\circ}\right.$ $18^{\prime}$ E) from rescue excavation before new construction. Comments: CRD-1 $\sigma: 3190$ to 2865 вс; (IAT): vessel dates tomb to Middle Bronze age on Cyprus (ca 1925 to $1600 \mathrm{BC}$ ). Calibrated date is earlier than conventional dating for Early Bronze age, but note that calibrated date for Episkopi-Phaneromeni (Late Bronze age IA in Cyprus) also appears to be 500 yr too early (R, 1977, v 19, p 189).

Greece

\section{Voidodkoilia series}

Tholos Tomb of Thrasymedes, NW of town of Voidokoilia, near Pylos $\left(30^{\circ} 22^{\prime} \mathrm{N}, 21^{\circ} 45^{\prime} \mathrm{E}\right)$, which contains Neolithic sherds, shows long and continuous use during Mycenaean period. Originally excavated by Spyridon Marinatos in 1956 and 1957, tomb was re-examined in 1977. Samples coll by G S Korres, Univ Athens and subm 1978 by H N Michael, Univ Mus, Univ Pennsylvania. 
P-2846. Sample V-1978-2

$5810 \pm 410 *$

Six small samples of charcoal and soil from depth 0.53 to $1.75 \mathrm{~m}$ in

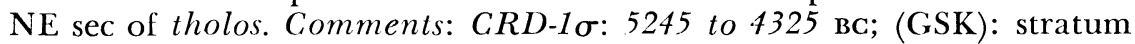
disturbed by digging in 1923.

P-2848. Sample V-1978-4

$4810 \pm 280 *$

Three small samples of charcoal and soil from interior of tholos. Comment: CRD-1 $\sigma: 3895$ to 3345 вс.

P-2850. Sample V-1978-5B

$4360 \pm 350 *$

Fourteen small samples of charcoal and soil from loci of pithos 1 and 5 in SE sec of tholos. Comment: $\mathrm{NaOH}$ pretreatment, CRD-1o: 3520 to 2620 BC.

\section{P-2852. Sample V-1978-7}

$4000 \pm 280 *$

Charcoal from vessel $\alpha$ (alpha) in dromos. Comment: CRD-1 $\sigma: 2930$ to 2155 BC.

\section{P-2853. Sample V-1978-8}

$4090 \pm 260 *$

Soil with charcoal and ash from vessel $\gamma$ (gamma) from dromos interior. Comment: CRD-1 $\sigma: 3035$ to 2315 BC.

\section{P-2854. Sample V-1978-9}

$4970 \pm 270 *$

Charcoal and burned soil contained in vessel $\beta$ (beta) from interior

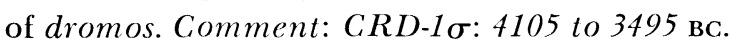

\section{P-2855. Papoulia Tumulus, Sample PAP-1978-1}

$$
3420 \pm 60
$$

Ash and charcoal from Papoulia Tumulus, a horseshoe-shaped structure of stone construction between villages of Platanos and Papoulia, in Pylos dist $\left(30^{\circ} 22^{\prime} \mathrm{N}, 21^{\circ} 45^{\prime} \mathrm{E}\right)$. Sample from right-central part of interior in niche. Coll 1978 by $\mathrm{G} S \mathrm{~S}$ Korres, Univ Athens and subm by $\mathrm{H} \mathrm{N}$ Michael. Comments: CRD-1 $\sigma: 1880$ to 1675 BC; (GSK): date expected to be Middle Helladic (1900 to $1600 \mathrm{BC}$ ) or perhaps Early Helladic.

\section{Ayios Stephanos series}

Ayios Stephanos is settlement site on flat-topped hill with burials throughout, ca $45 \mathrm{~km}$ SSE of Sparta, Laconia $\left(22^{\circ} 39^{\prime} \mathrm{E}, 36^{\circ} 48^{\prime} \mathrm{N}\right)$. Samples coll 1973, 1974, 1977 and subm by Lord William Taylour (1972), Cambridge Univ, England (Rutter \& Rutter, 1976).

P.2568. Sample 1 (1973)

$3160 \pm 60$

Charcoal from $\operatorname{Tr} \mathrm{N}(\Gamma)$ T.IA, Level 4, (20) ca 1.1m below surface. Com-

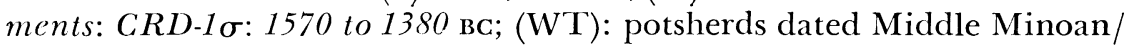
Late Helladic I.

\section{P.2569. Sample 2 (1973)}

Charcoal from Tr N (Г) T.I, Level 5, Rm II (35), ca $1.2 \mathrm{~m}$ below surface. Comments: CRD-1 $\sigma$ : 1650 to 1085 BC; (WT): no potsherds later than end of MH. 
P-2966. Sample 7 (1977)

$4100 \pm 230 *$

Charcoal and soil from $\operatorname{Tr} \mathrm{N} / \Gamma 1$, Level 44-W, balk (56). Comment: CRD-1 $\sigma: 2945$ to 2515 BC.

P-2969. Sample 12 (1977)

$\mathbf{3 5 1 0} \pm \mathbf{5 0}$

Charcoal from wooden plank, $\operatorname{Tr} \mathrm{N}$ 1, threshold to apse of apsidal bldg. Comments: CRD-16: 1970 to $1740 \mathrm{BC}$; (WT): should be appreciably older than bldg.

P-2965. Sample 6 (1977)

$4010 \pm 230 *$

Charcoal and soil from Tr N.1, Level 44-SW (52). Comments: CRD$1 \sigma$ : 2890 to $2305 \mathrm{BC}$; (WT): sample found in apse, sealed by debris and collapsed bldg material, of large MH II apsidal bldg (burned). General context is similar to P-2966, -2969 (above) and P-2967 (below).

P-2967. Sample 8 (1977)

$\mathbf{3 9 3 0} \pm \mathbf{5 0}$

Charcoal from Tr N 1, Levels 44-SE, 44-E, balk (53) (59). Comments: CRD-1 $\sigma$ : 2555 to $2325 \mathrm{BC}$; (WT): sample from main $\mathrm{rm}$ of large $\mathrm{MH}$ II apsidal bldg (burned) and sealed by debris and thick layer of collapsed bldg material. General context similar to P-2965, -2966, and -2969.

P-2790. Sample 8 (1974)

$\mathbf{4 1 5 0} \pm \mathbf{5 0}$

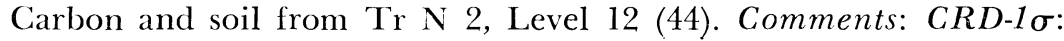
2900 to $2650 \mathrm{BC}$; (WT): sample from MH III level, same level as P-2965.

${ }^{14} \mathrm{C}$ date corresponds closely with pottery.

P-2958. Sample $10(1974)$

$4040 \pm 210 *$

Charcoal from Tr N 2, Level 13 (45). Comments: CRD-1o: 2905 to $2315 \mathrm{BC}$; (WT): sample found inside almost complete kantharos from MH III level; almost certainly related to P-2959, ${ }^{14} \mathrm{C}$ date corresponds closely with pottery.

P-2959. Sample 9 ( 1974)

$3720 \pm 250 *$

Charcoal from $\operatorname{Tr} \mathrm{N} 2$, Level 13 (45). Comments: CRD-10: 2435 to $1765 \mathrm{BC}$; (WT): sample found surrounding almost complete kantharos from MH III level; clearly related to P-2958.

P-2964. Sample 5 (1977)

$\mathbf{3 4 7 0} \pm 240 *$

Charcoal and soil from $\operatorname{Tr} \mathrm{N} 2$, Level 48 (48). Comments: CRD-1o: 2135 to $1580 \mathrm{BC}$; (WT): sample from fill of shaft above large MH III cist tomb (shaft grave). Tomb is sealed by floor on and above which P-2790, -2959 , and -2958 were coll. Pottery dates tomb to MH III.

P-2968. Sample 10 (1977)

$3770 \pm 210 *$

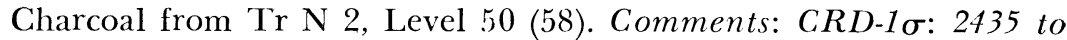
1910 BC; (WT): sample from fill above and on beaten earth floor due S of large MH II apsidal bldg. Assoc pottery is early MH II. Deposit and bldg are probably contemporaneous. 
P-2570. Sample 3 (1973)

Charcoal from Tr H, Level 3 , ca $50 \mathrm{~cm}$ below surface, on level with

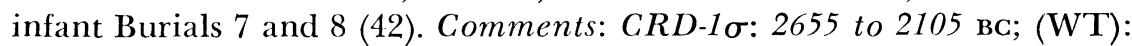
potsherds predominately $\mathrm{MH}$ and sample seems to agree.

P-2571. Sample 4 (1973)

$\mathbf{3 5 5 0} \pm 220 *$

Charcoal from Tr H, Level 3 (47), found ca $80 \mathrm{~cm}$ below surface, on level with infant Burial 10. Comments: CRD-10: 2190 to $1680 \mathrm{BC}$; (WT): pure MH stratum, but late, seems to be same date as P-2570, although from different sec of trench.

P-2962. Sample 4 (1977)

$\mathbf{3 9 0 0} \pm \mathbf{2 5 0} *$

Charcoal and soil from $\operatorname{Tr} \Lambda 3 / \Lambda 4$, Level XXXV (97). Comments: CRD-1 $\sigma$ : 2865 to $2000 \mathrm{BC}$; (WT): assoc with MH III yellow Minyan kantharos and late MH II grooved Minyan goblet.

P-2963. Sample 5 (1977)

$3620 \pm 60$

Charcoal and soil from $\operatorname{Tr} \Lambda 3 / \Lambda 4$, Level XXXVI (98). Comments:

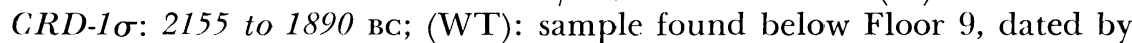
decorated Minyan goblet MH II (?late), and above deposit containing ladle, MH II (?early).

P.2961. Sample 4 (1977)

$4080 \pm 60$

Charcoal from Tr I/II/III, Area ep/ex (120). Comments: NaOH pretreatment; CRD-1 $\sigma: 2870$ to $2545 \mathrm{BC}$; (WT): sample possibly from wooden post; latest pottery MH II. ${ }^{14} \mathrm{C}$ date corresponds closely with pottery.

\section{P-3046. Sample $P: 1$}

$4200 \pm 240 *$

Charred wood from Akrotiri, Thera, Santorini I. $\left(36^{\circ} 21^{\prime}\right.$ N, $24^{\circ} 26^{\prime}$ E). Sample from Middle Cycladian, Akrotiri region, $\mathrm{N}$ entrance delta, E side, E of LM house with broken staircase (House Delta); found with older pumice pebbles. Coll 1978 by W.L Friedrich, Aarhus Univ, Denmark and H Pichler, and subm 1979 by P P Betancourt, Univ Pennsylvania. Comment: CRD-1 o: 3075 to 2545 BC.

\section{Near East}

Egypt

\section{E Karnak series}

E Karnak (Luxor) is in Nile Valley of Upper Egypt $\left(25^{\circ} 43^{\prime} \mathrm{N}, 32^{\circ}\right.$ $29^{\prime}$ E). Site, town of ancient Thebes, possibly has cultural correlation with Kushite-Saite period, ca 750-350 вс (Redford, 1977; 1978; 1979). Coll and subm by D B Redford, Univ Toronto, Canada.

General Comment: all samples are wood (id by Rowena Gale, Jodrell Royal Botanic Gardens, Surrey, England) and from destruction of large and imposing bldg, possibly from roofing beams.

P.3113. Sample HA I (14)

Wood from black stratum beneath Stratum 7. Comment: $\mathrm{NaOH}$ pretreatment; CRD-10: 815 to $765 \mathrm{BC}$. 
Wood (hazel, Corylus sp) from same loc. Comment: $\mathrm{NaOH}$ pretreatment; CRD-1 $\sigma: 800$ to 740 BC.

P-3114. Sample HA III (12)

$\mathbf{2 5 5 0} \pm \mathbf{5 0}$

Wood (Acacia sp) from same loc. Comment: NaOH pretreatment; CRD-1 $\sigma: 800$ to 740 BC.

P-3112. Sample HA IV (9)

$2860 \pm 40$

Wood (Tamarix sp and palm) from same loc. Comment: $\mathrm{NaOH}$ pretreatment; CRD-1 $\sigma: 1125$ to $1010 \mathrm{BC}$.

P-3115. Sample HA IV (6) $2210 \pm 50$

Wood (Acacia sp) from same loc. Comment: NaOH pretreatment. CRD-1 $\sigma: 400$ to 175 BC.

Iran

Eshkaft-e Gavi series

Charcoal (probably wood) from Eshkaft-e Gavi, Fars prov ( $29^{\circ} 52^{\prime} \mathrm{N}$, $52^{\circ} 45^{\prime}$ E). Coll 1978 by Michael Rosenberg, Anthropol Dept, Univ Pennsylvania, and subm 1981 by R H Dyson, Jr, Univ Mus, Univ Pennsylvania. General Comment (MR): samples come from Upper Paleolithic levels and dates are consistent with artifact types.

P.2861. Sample Lot 16 $>27,610 *$

Charcoal; depth ca 95 to $105 \mathrm{~cm}$.

P-2862. Sample Lot 17

$>27,970 *$

Charcoal; depth ca 95 to $105 \mathrm{~cm}$.

\section{P-2863. Sample Lot 18}

Charcoal; depth ca 95 to $105 \mathrm{~cm}$.

\section{P-2864. Sample Lot 19}

Charcoal; depth 105 to $113 \mathrm{~cm}$.

P-2865. Sample Lot 22

Charcoal; depth 105 to $122 \mathrm{~cm}$.

P-2866. Sample Lot 24

Charcoal; depth 122 to $135 \mathrm{~cm}$.

\section{Tepe Hissar series}

Tepe Hissar is loc at Damghan $\left(36^{\circ} 09^{\prime} \mathrm{N}, 59^{\circ} 22^{\prime} \mathrm{E}\right)$. In 1931 and 1932, Erich Schmidt conducted excavations at this complex of mounds for Univ Mus, Univ Pennsylvania. Most artifacts and pottery discussed by Schmidt $(1933 ; 1937)$ came from graves rather than occupation levels. This cemetery data formed the basis of his sequence. In 1976, a joint Hissar Restudy Proj was organized by Univ Mus, Turin Univ and Iran 
Center for Archaeol Research. One major goal of this restudy was to examine stratigraphy of site in order to construct revised chronol linked directly to occupation levels. Samples reported here were coll 1976 and subm by R H Dyson, Jr, with significant revision of Schmidt's dating of architectural remains (Dyson \& Howard, in press).

General Comment (RHD): samples were selected from four parallel sequences of site: Main Mound, N Flat, S Hill, and Twins. These should agree horizontally and be internally consistent. The following represent 1976 results:

Period I (earliest levels reached in 1976: later painted pottery (Schmidt IC (IIA)) 1st half, 4th millenium BC (P-2622, -2774, -2519, -2623, -2764).

Period II (earliest levels with majority of gray pottery (largely Schmidt IIB)) 2nd half, 4th millennium BC (P-2703, -2617, -2706, -2698, -2615, -2700, $-2704,-2699,-2715,-2773,-2766,-2759,-2767,-2708,-2710,-2621,-2707$, $-2711,-2709,-2760)$. Lapis lazuli working and copper smelting fully documented in this time range.

Period III (later gray pottery levels (Schmidt (IIIB)), 2nd half, 3rd millennium BC (P-2618, -2701).

Period III (end of sequence (Schmidt IIIC)), 1st quarter, 2nd millennium BC (P-2620).

Chronology indicates date in 2nd half of 3rd millennium $\mathbf{B C}$ for Burned Bldg and redates exposed architecture of Main Mound (Bldgs 1, 2, and 3) to Period II (originally dates IIIB by Schmidt (1937)). In 1976 revision, use of Schmidt's A, B, C subdivisions has been dropped since they were not defined on basis of actual stratigraphy at site. Schmidt's Periods and 1976 Revision Stages will be reported as SP and RS, respectively. Comments on S Hill samples by Maurizio Tosi (MT), ISMEO, Rome.

Samples from Main Mound

\section{P-2620. Sample H76-CS6}

$3610 \pm 70$

Charcoal, CG90 Balk [P] (1), Lot 4, Feature 1. Comments: CRD-1 $\sigma$ : 2150 to 1885 BC. (RHD): assoc with Wall 42, CG90 Balk 1. Highest preserved stratum, SP-IIIC, RS-A (= Period III).

P-2618. Sample H76-CS75

$3950 \pm 60$

Charcoal and soil, DG20. Comments: $\mathrm{NaOH}$ pretreatment. CRD-1 $\sigma$ : 2640 to 2390 BC: (RHD): immediately below row of four hearths, SP-IIIB, RS-B/C (= Period III).

P-2708. Sample H76-CS51

$\mathbf{4 4 4 0} \pm \mathbf{5 0}$

Charcoal, CG90 [11] Lot 31 (DG01). Comments: CRD-1 $\sigma: 3360$ to 2995 BC; (RHD): burned storeroom floor, relates to Bldg 3a SP-IIIB, RS-D (= Period II).

P-2710. Sample H76-CS30

$4380 \pm 70$

Charcoal, CG90 [7] Lot 37, Rm [7], Floor 2. Comments: NaOH pre-

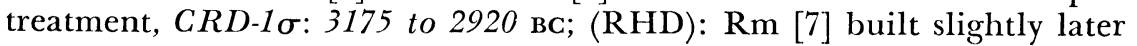


than Kitchen [1] and Kiln [3]. (Rm 7 is actually in DG 00), SP-IIIB, RS-D $(=$ Period II).

P-2621-A. Sample H76-CS10

$4550 \pm 70$

Charcoal, CG90 [2] Lot 23. Comments: $\mathrm{NaOH}$ pretreatment, CRD$1 \sigma$ : 3380 to 3160 вC; (RHD): alley between Kitchen [1] and Kiln [3], under uppermost surface, SP-IIIB, RS-D3 (= Period II).

P-2707. Sample H76-CS31

$4530 \pm 60$

Charcoal and soil, CG90 (3) Lot 35. Comments: CRD-1 $\sigma: 3375$ to 3150 BC; (RHD): Kiln [3] floor, contemporary with Kitchen [1], SP-IIB, RS-D3 (= Period II).

P-2709. Sample H76-CS4

$4540 \pm 60$

Charcoal, CG90 [1] Lot 11. Comments: NaOH pretreatment, CRD$1 \sigma: 3380$ to 3155 BC; (RHD): Kitchen [1] floor contemporary with Kiln [3], SP-IIIB, RS-D3 (= Period II).

P-2711. Sample H76-CS29

$4570 \pm 60$

Charcoal, CG90 [3] Lot 35. Comments: $\mathrm{NaOH}$ pretreatment, CRD$1 \sigma$ : 3385 to 3165 BC; (RHD): Kiln [3] floor, contemporary with Kitchen [1], SP-IIIB, RS-D3 (= Period II).

P-2622. Sample H76-CS73

$5060 \pm 320 *$

Charcoal and soil, DF09 [12] Lot 12, Balk 13 (12). Comments: CRD1 $\sigma$ : 4345 to 3515 BC; (RHD): trash lenses against lowest exposed walls below Bldg 2 which is contemporary with CG90 Kitchen [1] and Kiln [3], SP-I, RS-F (= Period I).

\section{P-2774. Sample H76-CS72}

$5750 \pm 60$

Charcoal and soil, DF09 Lot 5, Balk 13 (9). Comments: CRD-1 $\sigma$ : 4590 to 4545 BC; (RHD): sample was strat above P-2622 and should have been younger. It is below Bldg 2 (Stage D), SP-I, RS-E (= Period I).

P-2760. Sample H76-CS20

$\mathbf{4 5 3 0} \pm \mathbf{5 0}$

Charcoal, CG90 Balk [P] (4) Lot 15. Comments: NaOH pretreatment, CRD-1 $\sigma$ : 3375 to 3150 BC; (RHD): sample was below P-2620, RS-Period II.

Samples from $N$ Flat

P-2703. Sample H76-CS14

$4270 \pm 60$

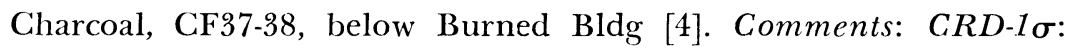
3030 to 2875 BC; (RHD): below P-2701, cf P-2617.

P-2701. Sample H76-CS13

$3860 \pm 60$

Charcoal, CF47, gray ash layer below W compound. Comments: CRD-1 $\sigma$ : 2420 to 2290 BC; (RHD): walls assoc with early Burned Bldg, SP-IIIB, RS-Period III. 
P.2617. Sample H76-CS2

$4420 \pm 50$

Charcoal, CF37, below Burned Bldg [1]. Comments: $\mathrm{NaOH}$ pretreatment, $C R D-1 \sigma$ : 3355 to 2955 BC; (RHD): sample was below P-2701, cf P-2703 (above), RS-Period II.

P.2706. Sample H76-CS18

$4240 \pm 70$

Charcoal, CF58 (3) [2]. Comments: $\mathrm{NaOH}$ pretreatment, CRD-1 $\sigma$ : 3000 to $2855 \mathrm{BC}$; (RHD): burned roof collapse in room attached to Buttressed Bldg, of P-2615, -2698, -2700 (below), RS-Period II.

P.2615. Sample H76-CS53A

$4350 \pm 50$

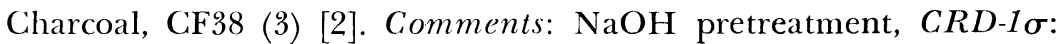
3165 to 2905 BC; (RHD): burned roof collapse in room attached to Buttressed Bldg, cf P-2698, -2700, RS-Period II.

\section{P-2698. Sample H76-CS53}

$4280 \pm 70$

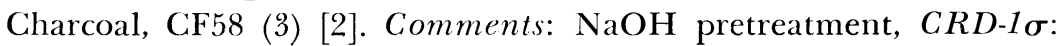
3040 to $2880 \mathrm{BC}$; (RHD): burned roof collapse in room attached to Buttressed Bldg, cf P-2615, -2700, -2706, RS-Period II.

P-2700. Sample H76-CS26

$$
4370 \pm 70
$$

Charcoal, CF58 (3) [3]. Comments: $\mathrm{NaOH}$ pretreatment, CRD-1\%: 3.170 to 2915 BC; (RHD): burned roof collapse in room attached to Buttressed Bldg, cf P-2615, -2698, RS-Period II.

\section{P-2704. Sample H76-CS16}

$$
4340 \pm 60
$$

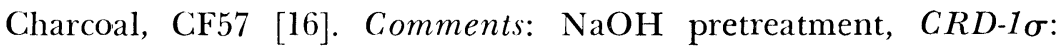
3160 to 2900 BC; (RHD): 2nd bldg level below ash and W compound walls (P-2701); lower than P-2701, higher than P-2699, RS-Period II.

P-2699. Sample H76-CS67

$4410 \pm 60$

Charcoal and soil, CF57 [16]. Comments: $\mathrm{NaOH}$ pretreatment, CRD. $1 \sigma: 3355$ to $2945 \mathrm{BC}$; (RHD): burned floor of niche in SW room of sq; lower than P-2704, higher than P-2619, RS-Period II.

\section{P-2619. Sample H76-CS69}

$4830 \pm 60$

Charcoal and soil, CF57 [16], base of Lot 3. Comments: NaOH pretreatment, CRD-1 $\sigma$ : 3685 to 3525 BC; (RHD): ash in deep test trench along W balk; lower than P-2699, higher than P-2623, RS-Period I.

P-2623. Sample H76.CS15

$\mathbf{5 2 0 0} \pm \mathbf{7 0}$

Charcoal and soil, CF57 [16]. Comments: $\mathrm{NaOH}$ pretreatment, CRD$1 \sigma$ : 4120 to $3875 \mathrm{BC}$; (RHD): from deepest ash level in SW corner of CF57; lower than P-2619, RS-Period I.

Samples from $S$ Hill

P-2715. Sample H76-CS48

$4450 \pm 60$

Charcoal, DG61 [15], from burned fill sealed in blocked door of reused burned structure at $\mathrm{E}$ end of $\mathrm{S}$ Hill. Comments: $\mathrm{NaOH}$ pretreatment, CRD-1 $\sigma: 3365$ to 3010 вG; (RDH): cf P-2773, RS-Period II. 
Charcoal and soil, DG80 [W] (2). Comments: $\mathrm{NaOH}$ pretreatment,

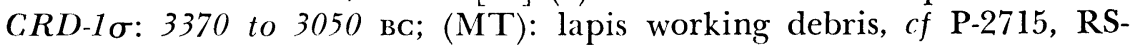
Period II.

\section{P-2766. Sample H76-CS65}

Charcoal and soil, DF89 [3], top of (3) sec, open areas S of buttressed

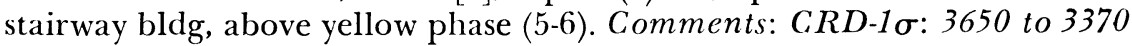
вC; (MT): Cu/lapis working area, RS-Period II.

\section{P-2759. Sample H76-CS52}

Charcoal and carbonized wood, DF89 [10]. Comment: $\mathrm{NaOH}$ pretreatment, $C R D-1 \sigma: 3670$ to $3500 \mathrm{BC}$.

P-2763. Sample H76-CS63

$4870 \pm 70$

Charcoal, DF79 [1] (2) from kiln debris. Comments: $\mathrm{NaOH}$ pretreatment, CRD-1 $\sigma$ : 3790 to 3635 BC; (RHD): date is Period I, but context needs clarification.

P-2765. Sample H76-CS59

$5020 \pm 70$

Charcoal, DF88 [5] (7), narrow space between $\mathrm{N}$ wall of buttressed stairway bldg and storeroom DF88 [1]. Comments: NaOH pretreatment, CRD-1 $\sigma: 3895$ to 3765 BC; (MT): bottom of fill, below metal working area, RS-Period I.

Samples from the Twins

\section{P.2767. Sample H76-CS40}

$4410 \pm 60$

Charcoal, FF94 (3). Comments: CRD-1 $\sigma: 3355$ to 2945 BC; (RHD): early gray pottery levels above painted pottery levels; RS-Period II.

\section{P-2764. Sample H76-CS38}

$4910 \pm 70$

Charcoal, FF95 (13), N of burned wall. Comments: CRD-1 $\sigma: 3860$ to 3650 BC; (RHD): dates terminal burned structure of painted pottery period, RS-Period I.

Israel

\section{Haifa series}

Suspected shipwreck from underwater rescue excavation, off coast of Haifa $\left(32^{\circ} 50^{\prime} \mathrm{N}, 34^{\circ} 90^{\prime} \mathrm{E}\right)$. Est age ca 1200 BC (Wachsmann \& Raveh, 1981). Coll and subm 1981 by Robert Maddin, Univ Pennsylvania.

\section{P-3099. Sample M23}

$2560 \pm 360 *$

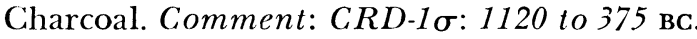

P-3226. Sample Hahotrim-M23

Wood or charred wood. Comment: CRD-1 $\sigma: 800$ to $420 \mathrm{BC}$, smaller uncertainty than that for P-3099 is due to extended counting period. 
Jordan

\section{Baq'ah Valley series}

Series of Late Bronze age burial caves are assoc with settlement at Khirbet Umm ad-Dananir, Baq'ah Valley $\left(35^{\circ} 40^{\prime} 20^{\prime \prime} \mathrm{N}, 32^{\circ} 40^{\prime} 10^{\prime \prime} \mathrm{E}\right.$ ) (McGovern, 1979; 1980; 1981a,b; 1982; McGovern, Harbottle, \& Wnuk, 1982; McGovern, Piggott, \& Notis, 1982). Coll and subm 1981 by P E McGovern, MASCA, Univ. Mus.

General Comment (PMcG): there are no previous ${ }^{14} \mathrm{C}$ dates for Late Bronze age on Transjordan plateau. Cultural sequence may be staggered vis-a-vis W Bank and Israel. Pottery sequence, 1600 to 1100 BC.

\section{P.3209. Sample B3.41/8 \& B3.51/8}

Charcoal from Cave B3, Jebel al-Qesir, Basket B3.41, Loc 8, area along back W wall of cave upper burial layer. Comments: $\mathrm{NaOH}$ pretreatment, CRD-1 0 : 1655 to 1405 BC; (PEMcG): Late Bronze II (ca 1400 to $1200 \mathrm{BC})$.

\section{P-3210. Sample B3.46/8}

$3350 \pm 70$

Charcoal from Cave B3, Jebel al-Qesir, Basket B3.46, Loc 8, upper burial layer along back $\mathrm{W}$ wall of cave, $\mathrm{S}$ of Crania 1 and 2. Comments:

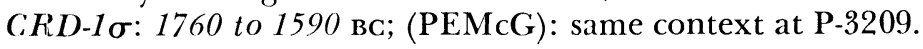

\section{P-3216. Sample V2.54/18-1}

$3440 \pm 60$

Charcoal from Khirbet Umm ad-Dananir, Field V, upper ashy layer covering and $\mathrm{S}$ of Wall 20, Area 2, Basket V2.54, Loc 18. Comments: ChD-1 $\sigma$ : 1890 to 1685 BC; (PEMcG): fill mixed with potsherds of Late Bronze I (ca 1600 to $1400 \mathrm{BC}$ ) and Iron Age IIC (ca 650 to $500 \mathrm{BC}$ ) from strat settlement site of Late Bronze age to Byzantine and Ottoman periods.

\section{P.3217. Sample V2.54/18-2}

$\mathbf{3 7 7 0} \pm \mathbf{7 0}$

Charcoal from Khirbet Umm ad-Dananir, Field V, lower ashy layer covering and S of Wall 20, Area 2, Basket V2.54, Loc 18. Comment: CRD. Io: 2335 to $2135 \mathrm{BC}$.

\section{P-3218. Sample V2.13/6}

$\mathbf{2 5 0} \pm \mathbf{5 0}$

Dessicated wood from Khirbet Umm ad-Dananir, Field V, surface of Loc 6, S side of Area 2, Basket V2.13. Comments: Stuiver corrected: AD 1795 to 1540; (PEMcG): Surface 6 is ca $1 \mathrm{~m}$ above ashy layer, Loc 18 of P-3217. Probably Ottoman (ca AD 1500 to 1900) floor, with re-use of Early Roman III (ca 4 BC to AD 73) bldg.

P-3219. Sample V2.55/19-5

$$
\mathbf{3 5 8 0} \pm \mathbf{7 0}
$$

Charcoal from Khirbet Umm ad-Dananir, Field V, Area 2, Loc 19, Basket V2.55, carbonized beams covering burned animal bones and pottery. Comments: $\mathrm{NaOH}$ pretreatment, CRD-1 $\sigma: 2120$ to $1865 \mathrm{BC}$; (PEMcG): pit is just below ashy layer, Loc 18 of P-3217. 


\section{Lebanon}

\section{Sarafand series}

Sarafand (ancient Sarepta) $\left(33^{\circ} 28^{\prime} \mathrm{N}, 35^{\circ} 18^{\prime} \mathrm{E}\right)$ is adjacent to harbor of village of Sarafand, ca $12.87 \mathrm{~km} \mathrm{~S}$ of Sidon on road to Tyre. Site represents most extensive and best strat remains of Phoenician civilization yet excavated. Coll and subm 1974 by J B Pritchard (1975), Univ Mus. For previous dates from this site, see P-1944 to -1948, -1950, and -1951 (R, 1974, v 16, p 222-223).

\section{P-2857. Sample II-A-2, Level 4-4 $2480 \pm 40$}

Charcoal from Hellenistic stratum. Comment: $\mathrm{NaOH}$ pretreatment, CRD-1 0 : 780 to 540 BC.

\section{P-2858. Sample II-A-8, Level 7}

$\mathbf{2 9 3 0} \pm \mathbf{5 0}$

Charcoal from Late Bronze age level. Comments: $\mathrm{NaOH}$ pretreatment, CRD-1 $\sigma: 1265$ to 1045 BC.

P-2859. Sample II-A-9, Level 7 $3030 \pm 250 *$ 10) $10 \mathrm{BC}$.

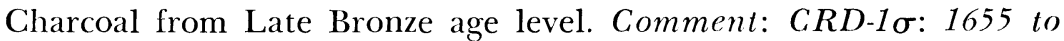

P-2860. Sample II-A-9, Level 8

$2950 \pm 40$

Charcoal from Late Bronze age level. Comment: $\mathrm{NaOH}$ pretreatment,

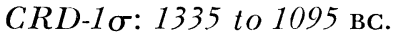

\section{Turkmenian SSR}

\section{USSR}

\section{P-3079. Sumbar Cemetery, Sample I.I 977}

$4860 \pm 60$

Charcoal and feces from bottom of Grave 174, depth $1.2 \mathrm{~m}$, catacomb tomb in Sumbar Cemetery, Kara Kala township, Kara Kala region (38 $\left.30^{\prime} \mathrm{N}, 50^{\circ} 10^{\prime} \mathrm{E}\right)$. Cemetery related to Gray Ware, pottery culture of $\mathrm{N}$ Iran (Late Bronze-Early Iron age) (Dolukhanov, 1979; Khlopin, 1977; Okladnikov, 1956). Coll 1976 by I N Khlopin and subm 1978 by $\mathrm{P}$ M Dolukhanov, Inst Archaeol, Leningrad. Comments: $\mathrm{NaOH}$ pretreatment,

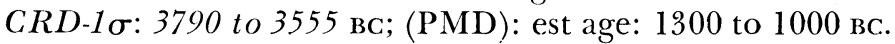

\section{Djebel Cave series}

Djebel Cave is near town of Djebel, Krasnovodsk Oblast' $\left(39^{\circ} 40^{\prime} \mathrm{N}\right.$, $50^{\circ} 10^{\prime} \mathrm{E}$ ). Site was originally excavated in 1956 by A P Okladnikov. Cave is cut in Upper Cretaceous limestone, S extremity of Great Balkan Ridge. Coll 1976 and subm 1978 by P M Dolukhanov. For previous date from this site, see Le-1, $6030 \pm 240(\mathrm{R}, 1965, \mathrm{v}$ 7, p 226).

General Comment (PMD): strat deposits of Mesolithic-Early Neolithic age. Sequence reflects evolution of local Neolithic tradition based on food gathering; more or less contemporaneous with early agricultural civilization of Djeitoun, further E.

\section{P-3080. Sample Djebel 1}

$$
2170 \pm 210 *
$$

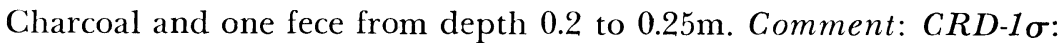
420 BC to AD 20. 
P-3083. Sample Djebel 2

$1360 \pm 180 *$

Charcoal from depth 0.3m. Comment: CRD-1 $\sigma$ : AD 450 to 880 .

P-3082. Sample Djebel 3

$4520 \pm 240 *$ 2905 BC.

Charcoal and feces from depth $0.4 \mathrm{~m}$. Comment: CRD-1 $\sigma$ : 3650 to

P-3081. Sample Djebel 4

$6140 \pm 80$

Charred twigs from depth 0.8 to $0.85 \mathrm{~m}$. Comment: CRD-1 $\sigma: 5255$ to 4940 BC.

Far East

India

\section{Dimapur, Nagaland series}

Dimapur is medieval site ca $77 \mathrm{~km} \mathrm{NW}$ of Kohima, Nagaland $\left(25^{\circ} 54^{\prime}\right.$ N. $93^{\circ} 45^{\prime} \mathrm{E}$ to $94^{\circ} 0^{\prime} \mathrm{E}$ ). Samples coll 1980 by Vikuosa Nienu, Univ California, Berkeley and subm 1982 by George Dales, Dept S and SE Asian Studies, Univ California, Berkeley.

\section{P.3124. Sample, Layer 4}

$1530 \pm 180 *$

Charcoal from $1.2 \mathrm{~cm}$ below surface level. Comments: Stuiver corrected: AD 270 to 660; (VN): Medieval period.

\section{P.3125. Sample, Layer 5}

$1300 \pm 180 *$

Charcoal from $1.35 \mathrm{~cm}$ below surface level. Comments: Stuiver corrected: aD 570 to 940; (VN): Medieval period.

\section{Puraka, Nagaland series}

Puraka is Neolithic-Iron age site located in Meluri Block, Phek dist, ca $25 \mathrm{~km}$ from Meluri, Nagaland $\left(25^{\circ} 45^{\prime} \mathrm{N}, 94^{\circ} 40^{\prime} \mathrm{E}\right)$. Coll 1980 by Vikuosa Nienu and subm 1982 by George Dales.

\section{P-3122. Sample, Layer 2}

$1390 \pm 200^{*}$

Charcoal from $25 \mathrm{~cm}$ below surface level. Comments: Stuiver calibrated: AD 430 to $780 ;(\mathrm{VN})$ : from post hole, Neolithic or Iron age.

\section{P-3123. Sample, Layer 3}

$\mathbf{2 5 8 0} \pm 200 *$

Charcoal from $85 \mathrm{~cm}$ below surface level. Comments: CRD-1 $\sigma: 900$ to 420 BC; (VN): Neolithic; traits of Hoabinhian culture are also present.

\section{Thailand}

Sites of Ban Chiang, Ban Tong, Ban Phak Top, Don Klang, Ban I Loet, Ban Puan Phu, and Non Khaw Wong were excavated 1974 through 1978 by NE Thailand Archaeol Project under joint auspices of Univ Mus, Univ Pennsylvania and Thai Fine Arts Dept.

\section{Ban Chiang series}

Ban Chiang, on N Khorat Plateau, Changwat (Prov) Udon Thani $\left(17^{\circ} 24^{\prime} \mathrm{N}, 103^{\circ} 15^{\prime} \mathrm{E}\right)$ was excavated by NE Thailand Archaeol Proj in 1974 and 1975 under joint direction of late Chester Gorman, Univ Mus, 
and Pisit Charoenwongsa, Thai Fine Arts Dept (Gorman \& Charoenwongsa, 1976; White, 1982). Comments by Joyce White, Univ Mus.

General Comment (JW): this site is important in establishing broad chronol framework for settlement of $\mathrm{N}$ Khorat Plateau and for sociocultural development of lowland agrarian socs in region (pre-metal, bronze, and iron using periods). Two seasons of excavation, designated BC (1974) and BCES (1975), were conducted at non-adjacent parts of mound. Burials were numbered consecutively beginning with Burial 1 for each season. Since each square of each season was excavated as separate unit, layer nos. do not necessarily correspond. Archaeol discussions of dates in individual sample comments are based on calibrated dates.

P-2240. BC Bag 907

$3120 \pm 220 *$

Charcoal and soil from BC Sq B5, Layer 10, depth $1.58 \mathrm{~m}$ while exposing Burial 20. Comments: CRD-1 $\sigma$ : 1675 to 1220 BC; (JW): Burial 20 had unique assemblage of bone artifacts (White, 1982, p 24).

\section{P-2265. BC Bag 987}

$4830 \pm 310^{*}$

Soil and charcoal from BC Sq B6, Layer 14 , in soil matrix near, but apparently not assoc with Burial 25, depth 2.2 to $2.33 \mathrm{~m}$ at beginning of sterile soil horizon. Comments: CRD-1 $\sigma$ : 3915 to 3340 BC; (JW): with P-2452 (below) may date to initial settlement of site.

P-2262. BC Bag 1019

$2090 \pm \mathbf{2 3 0} *$

Soil and charcoal from BC Sq C3, SW quad, surface of Layer 7, depth $1.5 \mathrm{~m}$, Burial 19. Comments: CRD-1 $\sigma$ : 400 BC to AD 55; (JW): assoc with red painted pottery. Date consistent with P-2241 and -2244 ( $c f$ below), also assoc with Late Period painted pottery.

\section{P-2242. BC Bag 1102}

$3790 \pm 240 *$

Charcoal and soil from BC Sq C3, SE quad, Layer 8, from excavation

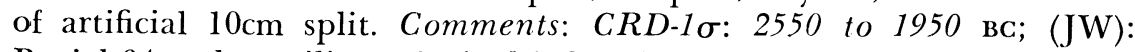
Burial 34 and curvilinear incised infant burial jar with serpentine appliqué was found ca $20 \mathrm{~cm}$ beneath surface of Layer 8. Samples P-2245, -2271, and -2456 ( $c f$ below) produced comparable dates from contexts which overlie or are closely assoc with curvilinear incised pottery.

P-2406. BC Bag 500 (?)

$1720 \pm 190 *$

Charcoal from BC Sq C4, SE quad, surface of Layer 4. Comments: Stuiver calibrated: AD 35 to 570; (JW): charcoal probably assoc with collapsed sherds of untyped pot. This is most recent date from site.

\section{P-2241. BC Bag 756}

$2090 \pm 40$

Charcoal and soil sandwiched between stacked sherds projecting out from E baulk BC Sq C4, SE quad, Layer 7, Feature 1, depth $1.01 \mathrm{~m}$. Comments: CRD-1 $\sigma: 190$ to $10 \mathrm{BC}$; (JW): sherds of painted ware; date consistent with P-2244 ( $c f$ below) and P-2262 ( $c f$ above) which are also assoc with red painted ware. 
Charcoal and soil from BC Sq C4, SE quad, surface of Layer 14, depth 2.07 to $2.1 \mathrm{~m}$. Comments: CRD-1 $\mathrm{\sigma}$ : 1395 to $1230 \mathrm{BC}$; (JW): possible hearth area with unclear relationship to burial sequence. Apparent insect and root activity and possibility of old erosion surface may account for somewhat late date relative to depth.

\section{P-2245. BC Bag 1205}

$3570 \pm 230 *$

Soil and charcoal from BC Sq C4, SW quad, surface of Layer 14, depth 1.86 to $2.08 \mathrm{~m}$. Comments: CRD-1 $\sigma$ : 2205 to $1685 \mathrm{BC}$; (JW): assoc with Burial 40, curvilinear incised infant jar (White, 1982, p 23). Date inconsistent with P-2242 ( $c f$ above), -2271, and -2456 ( $c f$ below) which also overlie or are closely assoc with curvilinear incised pottery.

\section{P-2266. BC Bag 1335}

$4590 \pm 300^{*}$

Soil and charcoal from BC Sq C4, SW quad, Layer 14, depth $1.96 \mathrm{~m}$. Comments: CRD-10: 3680 to $2910 \mathrm{BC}$; (JW): assoc with Burial 40 (curvilinear incised burial jar). However, since P-2245 ( $c f$ above), also excavated in assoc with Burial 40, is more consistent with other samples assoc with curvilinear incised pottery such as P-2271 (cf below), P-2266 may derive from matrix into which Burial 40 intruded.

\section{P-2246. BC Bag 1018}

$\mathbf{3 0 4 0} \pm \mathbf{5 0}$

Charcoal and soil from BC Sq C5, SW quad, Layer 10, depth $1.73 \mathrm{~m}$, possibly assoc with Burial 23. Grave goods include bronze bangles, bronze adze head, baked clay pellets, and cordmarked pot with painted and in-

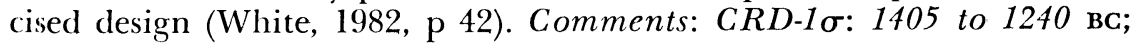
$(\mathrm{JW})$ : field records indicate that this sample and P-2261 ( $c f$ below) are assoc with Burial 23, but continued excavation in area and subsequent lab analysis revealed that Burial 23 cut into Burial 31 (P-2264, $c f$ below) and possibly another burial feature from earlier cultural phase which casts doubt on exact relationship of samples and reported feature assoc. Date of P-2246 is, however, consistent with P-2272 ( $c f$ below) which is assoc with burial of similar orientation and ceramics to Burial 23. See P-2454 (cf below) which also has burial and ceramic style related to Burial 29.

P.2261. BC Bag 1083

$3270 \pm 230 *$

Charcoal and mud from BC Sq C.5, S quads, Layer 11, depth 1.73 to $1.92 \mathrm{~m}$, possibly assoc with Burial 23. Comments: CRD-16: 1865 to 1365 BC; (JW): same doubtful sample relationship as for P-2246 ( $c f$ above). This date is however same as that for P-2454 (cf below) which is assoc with burial and ceramic style related to Burial 23.

P-2264. BC Bag 1211

$3130 \pm 210$

Soil and charcoal from BC Sq C5, NW quad, Layer 11, depth $1.86 \mathrm{~m}$. Comments: CRD-1 $\sigma$ : 1680 to $1225 \mathrm{BC}$; (JW): assoc with Burial 31 which was cut by Burial 23. See comments for P-2246 and -2261 . 
Charcoal from BC Sq C6, NW quad, Layer 8, depth 0.62 to $0.74 \mathrm{~m}$.

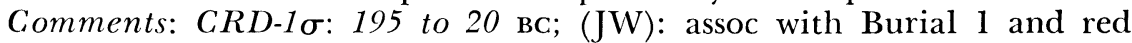
painted ceramics. Date consistent with P-2241 and -2262 ( $c f$ above), also assoc with Late Period red ceramics.

P-2247. BC Bag 918

$3610 \pm 230 *$

Soil and charcoal from BC Sq C6, SE quad, Layer 10, depth $1.02 \mathrm{~m}$.

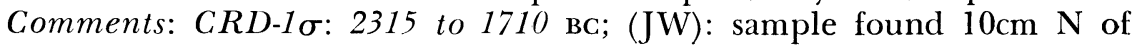
Burial 14 jaw which included red painted pottery, high tin wire necklaces, and opaque glass beads. Date unacceptably old in comparison with other samples assoc with comparable pottery; see P-2241, -2244, and -2262 (cf above). Burial was extensively disturbed by insects and roots.

P.2272. BC Bag 1167

$2950 \pm 210 *$

Charcoal and soil from BC Sq C6, SE quad, surface of Layer 15, depth 1.54m. Comments: CRD-1 $\sigma$ : 1430 to $865 \mathrm{BC;}(\mathrm{JW})$ : assoc with Burial 35; includes cordmarked and painted pottery comparable to Burial 23; see P-2246 and -2261 (above).

P-2271. BC Bag 1374

$\mathbf{3 5 7 0} \pm \mathbf{2 3 0} *$

Soil and charcoal from BC Sq C6, N quads, surface of Layer 18, depth $1.97 \mathrm{~m}, 10 \mathrm{~cm}$ from right arm of Burial 43. Comments: CRD-1 0 : 2205 to $1685 \mathrm{BC} ;(\mathrm{JW})$ : large curvilinear incised and appliquéd pot found over burial. Date consistent with samples overlying, or in assoc with curvilinear incised pottery; see P-2245 (above) and -2263, -2456 (below).

\section{P-2263. BC Bag 1377}

$4250 \pm 290 *$

Soil and charcoal from BCi Sq C6, N quads, Layer 19, depth $2.06 \mathrm{~m}$.

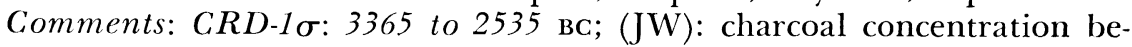
tween Burials 43 and 45, interred one atop the other. Curvilinear incised appliquéd pot found directly above Burial 43; see P-227 1 (above).

P.2664. BCES Bag 1383, 1785, and 1794

$\mathbf{2 3 0 0} \pm \mathbf{5 0}$

Charcoal and soil from BCES Sq D4, SE quad, surface of Layer 17 to surface of Layer 19, in general assoc with Burial 19. Comments: CRD-1o: 420 to 380 BC; (JW): Burial 19 overlay and had disturbed parts of Burial 24 (assoc with bronze-iron spearpoint) (White, 1982, p 80). Date appears inconsistent with P-2665 (cf).

P.2665. BCES Bags 1279, 1667, 1705, and $1714 \quad 2520 \pm 50$

Soil and charcoal from BCES Sq D4, SE quad, surface of Layer 17, Feature 3, from sherd scatter overlying Burial 19. Comments: CRD-1 $\sigma$ : 795 to $585 \mathrm{BC}$; (JW): due to greater coherence of combined sample proveniences, assoc of P-2665 with Burial 19 seems at least as acceptable as P-2669 ( $c f$ above). Date assoc with Middle Period scatter burial with white carinated pots and carinated pots with incised and painted shoulders (White, 1982, p 68). Date overlies Burial 24 and assoc bronze-iron spearpoint, oldest iron recovered from excavation. 


\section{P-2457. BCES Bag 2162}

$\mathbf{3 2 4 0} \pm \mathbf{5 0}$

Charcoal and soil from BCES Sq D4, SE quad, $10 \mathrm{~cm}$ spit into Layer

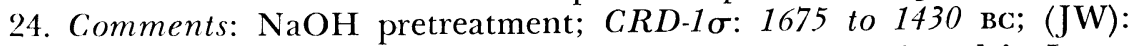
three cordmarked and appliquéd infant burial jars were found in Layer 27 of D4, SE quad, ca 20cm under Layer 24.

\section{P-2634. BCES Bag 2110}

Charcoal and soil from BCES Sq D4, NW quad, Layer 21, depth $272 \mathrm{~cm}$. Comments: NaOH pretreatment, CRD-1 $\sigma: 930$ to $825 \mathrm{BC} ;(\mathrm{JW})$ : sample coll from remnants of red-brown soil as it was removed from surface of gray soil stratum; may date beginning of red-brown soil stratum and possibly initiation of ritual involving shattering of white carinated pots over body (White, 1982, p 25).

\section{P-2455. BCES Bag 2248}

$\mathbf{2 8 3 0} \pm \mathbf{5 0}$

Charcoal from BCES Sq D4, SE quad, Layer 26. Comments: $\mathrm{NaOH}$ pretreatment, CRD-1 $\sigma$ : 1115 to 875 BC; (JW): sample is from charcoal feature in SE quad, possibly hearth, but date is somewhat recent for depth (see P-2457, above). It is possible that sample derived from base of post hole cut down from surface of gray stratum (Levels 21 and 22) directly over and to same depth $(299 \mathrm{~cm})$ as so-called hearth. If this is so, P-2455 is consistent with P-2634 ( $c f$ below) from interface of red/gray strata.

\section{P.2454. BCES Bag 2306}

$3270 \pm 180 *$

Soil and charcoal from BCES Sq D4, SW quad, surface of Layer 27, Feature 12, grave cut of Burial 59. Comments: $\mathrm{NaOH}$ pretreatment, CRDI o : 1865 to $1365 \mathrm{BC}$; (JW): Burial 59 includes globular cordmarked pot, style of which is related to that of BC Burial 23 (P-2246 and -2261, above); and is stratified over Burials 69 (P-2405, below) and 65 (P-2404, below).

\section{P-2405. BCES Bag 2656}

$3240 \pm 210 *$

Soil and charcoal from BCES Sq D4, SW quad, surface of Layer 29, Feature 23, excavated during removal of skeleton from Burial 69. Comments: CRD)-1 $\sigma$ : 1765 to 1340 вс; (JW): Burial 69 cuts flexed Burial 65 (P-2404, below) and is under Burial 59 (P-2454, above).

\section{P.2404. BCES Bag 2678}

$3000 \pm 200 *$

Soil and charcoal from BCES Sq D4, S quads, surface of Layer 29, within grave cut of Burial 65. Comments: CRD-1 $\sigma: 1545$ to 1015 BC; (JW): grave is flexed burial cut into yellow sterile soil matrix, and is cut by Burial 69 (see P-2405, above) and overlain by Burial 59 (P-2454, above). Date appears somewhat recent for strat position.

P-2452. BCES Bag 2111

$$
4750 \pm 240 *
$$

Charcoal and soil from BCES Sq D5, NW quad, Layer 27, removal of 10 to $20 \mathrm{~cm}$ spit. Comments: $\mathrm{NaOH}$ pretreatment: CRD-1 $\sigma: 3785$ to 3355 BC; (JW): sample from top of yellow sterile soil horizon, may date early settlement of site (see P-2265, above). 
P-2456. BCES Bag 2030

$3650 \pm 220 *$

Soil and charcoal from BCES Sq D5, W quads, surface of Layer 27,

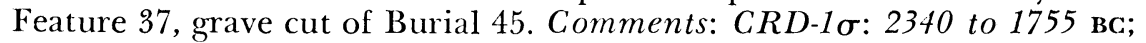
$(\mathrm{JW})$ : Burial 45 contained straight-sided, flat-bottomed, footless cordmarked pots with everted rim, probably contemporary with Beaker-style pot found in Burial 76 (P-2398, below). Burial 45 lies directly over Burial 57 which contains curvilinear incised pot and is disturbed.

P-2453. BCES 2285

$7180 \pm 70$

Charcoal and soil from BCES Sq D.5, NW quad, surface of Layer 30, Feature 3. Comments: $\mathrm{NaOH}$ pretreatment; CRD-1 $\sigma: 6290$ to $5705 \mathrm{BC}$; (JW): possible hearth; surrounding area is basically sterile soil matrix with no assoc sherds. Hearth is sealed by Burial 57 which contained curvilinear incised pot. This is oldest date and may derive from brief use of this site possibly by mobile group of people prior to settlement in 4th millennium BC by more sedentary population; see P-2265 and -2452 (above).

P-2451. BCES Bag 2322

$3580 \pm 240 *$

Soil and charcoal from BCES Sq D6, NE quad, surface of Layer 31, grave cut of Burial 60. Comments: CRD-1 $\sigma$ : 2215 to $1690 \mathrm{BC}$; (JW): Burial 60, cut into sterile soil, appears badly disturbed, as only skull and small incised pot were present.

P-2450. BCES Bag 2651

$2410 \pm 210 *$

Charcoal and soil from BCES Baulk D6/D7, surface of Layer 16, Feature 1 cut from surface of Layer 14. Comments: $\mathrm{NaOH}$ pretreatment, $C R D-1 \sigma: 800$ to $375 \mathrm{BC}$; (JW): date supports likelihood that sample derived from red layer (over gray layer). P-2634 and probably P-2455 (above) are dates from red/gray interface.

P-2668. BCES Bag 2770

$2800 \pm 50$

Soil and charcoal found while exposing Burial 31, from BCES Baulk D6/D7, Layer 20. Comments: CRD-1 $\sigma: 1100$ to 840 BC; (JW): sample, along with P-2633 (below), appears unacceptably young for strat context well within gray stratum, its Early Period grave style and ceramics which, based on overall chronol picture, should antedate ca 1500 BC. Burial 31 overlies Burial 76 (P-2398, below).

P-2633. BCES Bag 2773

$2600 \pm 60$

Soil and carbon from BCES Baulk D6/D7, surface of Layer 21, Burial

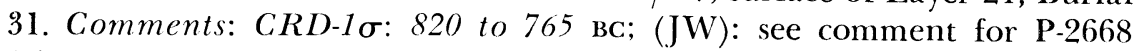
(above).

P-2398. BCES Bag 2834

$2480 \pm 240 *$

Charcoal and soil from BCES Baulk D6/D7, surface of Layer 27, Feature 5 from under pelvic area of Burial 76, flexed burial cut into sterile soil and assoc with bronze spearpoint and Beaker-type jar (White, 1982, p 35). Comments: CRD-1 0 : 820 to 395 BC; (JW): date seems unaccount- 
ably young for context and grave style; see P-2633 and -2668 (above). Based on overall chronol sequence, grave should antedate ca $1500 \mathrm{BC}$, and possibly $2000 \mathrm{BC}$; see P-2456 (above).

\section{P'etchabun Piedmont Survey}

Archaeol survey and three test excavations (Ban Puan Phu, Non K.haw Wong, and Ban I Loet) were conducted 1978 in area along piedmont of Petchabun Mts which form W border of Khorat Plateau, NE Thailand (Penny, ms), revealing relatively shallow and homogeneous archaeol deposits (excluding some apparently intrusive hist artifacts in Bian Puan Phu excavation). Most ceramics from excavations were similar to each other, to prehist surface collns from this survey, and to three surface collns from contiguous area of Pa Mong Survey (Bayard, 1980), but not similar to ceramics from other available sites on Khorat Plateau. A.bove three sites also had similar array of other artifacts including iron and iron slag.

\section{Ban Puan Phu series}

Ban Puan Phu site is in NE Thailand $\left(17^{\circ} 5^{\prime} \mathrm{N}, 101^{\circ} 48^{\prime} \mathrm{E}\right)$. Coll 1978 by J S Penny, Center Archaeol Investigations, Southern Illinois Univ at Carbondale and subm 1978 by late C F Gorman.

General Comment (JSP): site is apparently late "metal age" and hist.

\section{P-2938. BPP Bag 446}

$$
\mathbf{2 4 4 0} \pm \mathbf{5 0}
$$

Single large piece of charcoal from fired clay feature of unknown function from NEQ, Level 6, Feature 3. Comment: $\mathrm{NaOH}$ pretreatment, C.RD-1 $\sigma: 630$ to $415 \mathrm{BC}$.

\section{P-2939. BPP Bag 427}

$2680 \pm 210 *$

Charcoal from SEQ, Level 7, Burial 1. Comments: $\mathrm{NaOH}$ pretreatment, CRD-1o: 1105 to $745 \mathrm{BC}$; (JSP): strat relation of date to deposit is not precisely known, but there does not appear to be any possibility that clate relates to earlier (pre-iron) level, since none apparently exists at site.

\section{Non Khaw Wong series}

Non Khaw Wong site is in NE Thailand $\left(16^{\circ} 39^{\prime} \mathrm{N}, 101^{\circ} 47^{\prime} \mathrm{E}\right)$. Coll 1978 by J S Penny and subm 1978 by late C F Gorman.

General Comment (JSP): pre- or proto-hist "metal age" with possibility of pre-iron basal level.

P-2943. NKW Bag 258

$1980 \pm 180 *$

Charcoal and soil from Feature 3, NE half, Level 14. Comments: CRD-1 $\sigma$ : $195 \mathrm{BC}$ to AD 230; (JSP): this feature contained probable lid which is strikingly similar to painted lids from Don Klang (below) (Schauffler, 1976, Figs 3 and 4).

P-2944. NKW Bag 195

Charcoal and soil coll from Level 7 , arbitrary level near bottom of

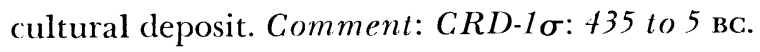


P-2945. NKW Bag 202

$2070 \pm 170 *$

Charcoal and soil from Level 7 , arbitrary level near bottom of cultural deposit. Comments: CRD-1 $\sigma: 275$ BC to AD 45; (JSP): this date and P-2944 overlap quite well at $1 \sigma$.

\section{Ban I Loet series}

Ban I Loet site is in NE Thailand ( $\left.16^{\circ} 57^{\prime} \mathrm{N}, 101^{\circ} 50^{\prime} \mathrm{E}\right)$. Coll 1978 by $\mathrm{J} S$ Penny and subm by late $\mathrm{C} F$ Gorman.

General Comment (JSP): pre- or proto-hist "metal age."

P-2940. BIL Bag 311

$2340 \pm 230 *$

Charcoal from Level 8, arbitrary level near base of excavation. Comment: CRD-1 $\sigma: 650$ to $175 \mathrm{BC}$.

\section{P-2941. BIL Bags 332 and 337}

$2460 \pm 210 *$

Charcoal from Feature 2, Levels 10 and 11 at base of excavation.

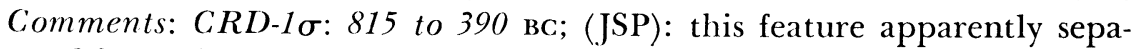
rated from higher deposits by erosion surface.

\section{Ban Phak Top series}

Ban Phak Top is ca $30 \mathrm{~km} \mathrm{~W}$ of Ban Chiang, Changwat (Prov) Udon Thani $\left(17^{\circ} 19^{\prime} \mathrm{N}, 103^{\circ} 2^{\prime} \mathrm{E}\right)$. Coll and subm 1975 by W M Schauffler (1976), Univ Mus.

\section{P-2407. Bag S188 (C14-26) $\quad 3900 \pm 70$}

Charcoal (from burned $\log$ or piece of wood) and soil from Layer 13.

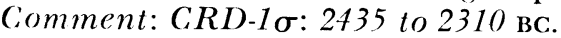

\section{P-2445. Bag S127 (C14-16) 2760 $\pm 170 *$}

Charcoal and soil from NEQ and SEQ, Layer 8a. Comment: CRD$1 \sigma: 1120$ to 790 BC.

\section{P-2446. Bag S134 (C14-17) $\quad 3050 \pm 60$}

Charcoal and soil from NWQ and SWQ, Layer 8a. Comment: $\mathrm{NaOH}$ pretreatment, CRD-1 $\sigma: 1410$ to $1245 \mathrm{BC}$.

P-2686. Bags S120 (C14-12), S121 (C14-13), S122 (C14-14), and S124 (C14-15) $3090 \pm 50$

Charcoal and soil from Layer 8 NEQ, SEQ, NWQ, and SWQ. Com-

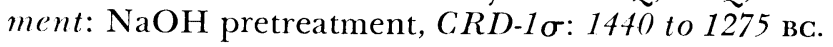

\section{P.2726. Bag S178 (C14-24) $\quad 3510 \pm 210 *$}

Charcoal and soil from Layer 12, SWQ soil matrix. Comment: CRD$1 \sigma: 2165$ to $1660 \mathrm{BC}$.

\section{P-2731. Bag S66 (C14-5)}

$3170 \pm 300 *$

Charcoal from surface of Layer 5, Feature 2. Comment: CRD-1 $\sigma$ : 1865 to 1090 BC. 


\section{P-2732. Bag 106 (C14-9)}

Charcoal and soil from Layer 7, SWQ. Comments: $\mathrm{NaOH}$ pretreatment, $C R D-1 \sigma: 1675$ to 1430 BC.

\section{Don Klang series}

Don Klang site is SW of Ban Chiang, Changwat (Prov) Udon Thani $\left(16^{\circ} 58^{\prime} \mathrm{N}, 102^{\circ} 32^{\prime} \mathrm{E}\right)$. Coll and subm 1975 by W M Schauffler (1976).

General Comment (WMS): first material from site to be reported.

\section{P-2416. Bag S427 (C14-54) $\quad 2140 \pm 60$} 145 BC.

Charcoal and soil underlying Burial 8. Comment: CRD-1 $\sigma: 255$ to

\section{P.2417. Bag S337 (C14-44)}

$1870 \pm 190 \%$

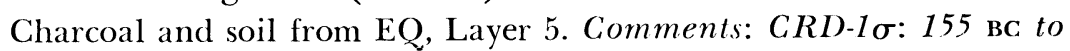
AD 380; (WMS): assoc with pot near E corner.

P.2448. Sample 38

$$
1900 \pm 200 *
$$

Soil and charcoal from NQ, Layer 5. Comments: CRD-1 $\sigma: 165 \mathrm{BC}$ to AD 260; (WMS): sample recovered during removal of half of Burial 2.

\section{P-2674. Bag S500 (C14-60)}

Soil and charcoal from WQ, Layer 8 , and surface of Layer 9, Feature 3. Comment: CRD-1 $\sigma$ : 630 to $415 \mathrm{BC}$.

P-2675. Bag S308 (C14-33)

$$
1920 \pm 50
$$
AD 75 .

Soil and charcoal from Layer 4, NQ. Comment: CRD-10: 5 BC to

P.2694. Bag S380 (C14-46, -47, -48, -49) $2040 \pm 50$ AD 20 .

Charcoal and soil from NQ, Layer 6. Comment: CRD-1 $\sigma: 170 \mathrm{BC}$ to

\section{Ban Tong series}

Ban Tong is in Changwat (Prov) Udon Thai $\left(17^{\circ} 22^{\prime} \mathrm{N}, 103^{\circ} 16^{\prime} \mathrm{E}\right)$. Coll and subm 1975 by W M Shauffler (1976).

\section{P-2418. Bag S1613 (C14-135)}

Charcoal from Layer 18, NEQ and SEQ, Burial 2. Comment: CRD$1 \sigma: 1400$ to $795 \mathrm{BC}$.

\section{P-2419. Bag S1640 (C14-142)}

Charcoal from Layer 20, SEQ. Comment: CRD-1 $\sigma: 3365$ to 2800 BC.

\section{P.2447. Bag S1614 (C14-138)}

$2460 \pm 170 *$

Charcoal and soil from Layer 18, NEQ, and SEQ, Burial 2. Comment: $C R D-1 \sigma: 800$ to 400 вс. 
P-2691. Bags S1571 (C14-121), S1578

(C14-123), $\mathbf{S 1 5 8 0}(\mathbf{C 1 4 - 1 2 0},-122)$, S1584 (C14-124), $\mathbf{S 1 5 8 8}(\mathbf{C 1 4 - 1 2 5})$, and $\mathbf{S 1 5 8 9}$ (C14-126, -127)

Soil and charcoal from Layer 16. Comment: CRD-1 : 1550 to 1360 BC.

P-2723. Bags S1026 (C14-78) and S1060 (C14-81, -82)

Charcoal and soil from NEQ 6 assoc with $\mathrm{Bl}$ and Feature 2. Comment: CRD-1 $\sigma: 915$ to 765 вс.

P-2724. Bag S1362 (C14-105)

$3220 \pm 200 *$ $1270 \mathrm{BC}$

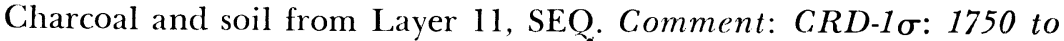

P-2725. Bag S1472 (C14-113)

$3080 \pm 180 *$

Charcoal and soil from Layer 14, NWQ. Comment: CRD-1 $\sigma: 1655$ to 1095 BC.

\section{P-2727. Bags S1322 (C14-99) and S1323}

\section{(C14-100)}

$3360 \pm 200 *$

Charcoal and soil from $S W Q$, coll from entire sq (not localized area). Comment: CRD-1 $\mathrm{\sigma}: 1945$ to $1420 \mathrm{BC}$.

\section{P-2730. Bags S1161 (C14-85), S1163}

$$
\text { (C14-86), and S1167 (C14-87) } \quad 3040 \pm 190 *
$$
$1035 \mathrm{BC}$

Charcoal and soil from Layer 8, NEQ. Comment: CRD-1\%: 1575 to

Belize

\section{Central America}

\section{Santa Rita Corozal series}

Santa Rita Corozal site, $1.6 \mathrm{~km}$ from Chetumal Bay, outside modern Corozal ( $18^{\circ} 23^{\prime} \mathrm{N}, 88^{\circ} 23^{\prime} \mathrm{E}$ ), is possible regional capital in N Maya Lowlands (Chase, 1982a). Coll and subm by D Z Chase, Dept Anthropol, Univ Pennsylvania.

General Comment: wood id by Jodrell Lab, Royal Botanic Gardens, Surrey, England.

\section{P-3076. Sample P6F/9-1}

$880 \pm 190 *$

Charcoal (family Leguminosae), Excavation $\mathrm{P} 6 \mathrm{~F}, 46 \mathrm{~cm}$ below surface, Structure 77, from later context in same trench as P-3074. Late phase of Late Postclassic (AD 1425 to 1550) (Sidrys, 1976). Comment: Stuiver corrected: AD 980 to 1290 .

\section{P-3074. Sample P6F/33-2}

$$
650 \pm 40
$$

Charcoal (family Burseraceae) from Excavation P6F, at least $1.2 \mathrm{~m}$ below surface, Structure 77. Early phase of Late Postclassic (AD 1325 to 
1425) sealed by several floor levels and covering contemporaneous midden deposit containing bone and pottery. Comments: $\mathrm{NaOH}$ pretreatment. Stuiver corrected: AD 1290 to 1390.

\section{P-3073. Sample P8C/9-1}

$\mathbf{7 4 0} \pm \mathbf{5 0}$

Charcoal from Excavation P8C, ca $40 \mathrm{~cm}$ below surface, Structure 81 . Sample may represent construction beam, Late Postclassic (AD 1425 to 1550). Comments: $\mathrm{NaOH}$ pretreatment. Stuiver corrected: AD 1260 to 1290 .

\section{P-3075. Sample P8C/9-1}

$\mathbf{7 0 0} \pm \mathbf{5 0}$

Charcoal (family Meliceae) from Excavation P8G, within altar area, ca. $90 \mathrm{~cm}$ below surface, Structure 81 . Sample assoc with individual burial from early phase of Late Postclassic (AD 1400) and may represent construction beam. Comment: Stuiver corrected: AD 1265 to 1375.

P.3077. Nohmul, Sample P1E/20-3

$1300 \pm 40$

Nohmul, N Maya-Lowlands $\left(18^{\circ} 14^{\prime} \mathrm{N}, 80^{\circ} 35^{\prime} \mathrm{E}\right)$, is island site with relatively long hist of occupation (Chase, 1982a; 1982b; Chase \& Chase, 1982). Charcoal from Excavation P1E, in Terminal Classic/Early Postclassic (AD 900 to 1200 ) structures ca $3.2 \mathrm{~m}$ below surface. Comments: CRDIor: AD 615 to 785 . Early Postclassic (AD 900 to 1200).

\section{Guatemala}

\section{Quirigua series}

Quirigua, Dept Isabel $\left(15^{\circ} 16^{\prime} \mathrm{N}, 89^{\circ} 03^{\prime} \mathrm{W}\right)$ is Classic Maya site (Ashmore \& Sharer, 1978; Sharer, 1978; Sharer \& Ashmore, 1979). Subm 1979 by R J Sharer, Univ Mus. Previous dates for samples from this site are reported in $\mathrm{R}, 1978, \mathrm{v} 20$, p 210-233.

General Comment (RJS): samples relate to Maya calendric dates and should add to calendric correlation as well as expand known sequence of construction and occupation at Quirigua.

\section{P-3084. Sample 16A/16}

$1310 \pm 40$

Carbon sealed in construction 4.6 to $4.8 \mathrm{~m}$ below summit of Structure IA-11 (N side of Ballcourt Plaza in site core). Comments: NaOH pretreatment, Stuiver corrected: AD 660 to 765 ; (RJS): est date, 7 th to 9 th century AI.

\section{P.3085. Sample 19R/2-1 and 2}

$1830 \pm 170^{*}$

Carbon from hole dug by vandals under disturbed "altar", assoc with platform of Structure 3C-14. Comments: Stuiver corrected: AD 15 to 405; (R.JS): est date, ca AD 500.

\section{P-3086. Sample 6F/45}

$\mathbf{1 4 5 0} \pm \mathbf{5 0}$

Charcoal from Acropolis, $\operatorname{Tr} 1$, construction Stage 2. Comments: $\mathrm{NaOH}$ pretreatment, Stuiver corrected: AD 545 to 640; (RJS): KinichAhau-wall platform construction or destruction of earlier wall, est date, 
ca AD 737 to 810 . Should be intermediate in date between: P-2536 (AD 590 \pm 50 ), P-2533 (AD 830-850 \pm 50 ), P-2535 (AD 860-880 \pm 180 ), P-2538 (AD $890 \pm 170),(\mathrm{R}, 1978, \mathrm{v} 20, \mathrm{p} 230-232)$.

\section{P-3087. Sample 6J/26}

$1440 \pm 40$

Carbon abuts Structure 1B-6-2nd (E side of Acropolis) which underlies PRANCE feature, construction Stage 3. Comments: Stuiver corrected: AD 570 to 640; (RJS): est date, ca AD 724 to 737.

P-3088. Sample 6L/33-1

$1290 \pm 40$

Charcoal from Acropolis, redeposited midden on floor of Structure 1B-Sub 3, construction Stage 2. Comments: Stuiver corrected: AD 1330 to 1250; (RJS): est date, ca AD 737 to 810.

\section{P-3089. Sample 19R/65-1 and 2}

$1970 \pm 50$

Carbon directly underlying clay floor of cache (SD 21) and sealed within Structure 3C-14. Comments: CRD-1 $\sigma: 35$ BC to AD 55; (RJS): est date, ca AD 500.

\section{P-3095. Sample 9B/22-1 and 2}

$1800 \pm 50$

Charcoal from underlying Structure 1A-10 (E flank of Great Plaza). Comments: Stuiver corrected: AD 130 to 320; (RJS): probably contemporary with or earlier than cache (SD 11): antedates construction of Structure 1A-10. Est date, ca AD 737 to 775 .

\section{P-3096. Sample 6J/50-1}

$\mathbf{1 7 3 0} \pm \mathbf{5 0}$

Carbon from charcoal and sherd layer underlying Structure 1B-6-2nd (E side of Acropolis) and overlaying chamber burial (SD 14), construction Stage 4. Comments: Stuiver corrected: AD 235 to 395; (RJS): est date, earlier than AD 724.

P-3097. Sample 10K/23

$420 \pm 40$

Charcoal from within collapse debris of Structure 2, Group A. Comments: $\mathrm{NaOH}$ pretreatment. Stuiver corrected: AD 1435 to 1485; (RJS): postdates abandonment (although carbon may have been in structure during use). Est date, 9th century AD.

\section{P-3098. Sample 18L/6-1 and 2}

$1830 \pm 50$

Charcoal from ca $200 \mathrm{~m}$ N of site-core (ditch Jn). Comments: Stuiver corrected: AD 75 to 235; (RJS): probably bldg material or furnishing for stone construction feature. Est date, 5 th to 6 th century aD.

P-3100. Sample 19R/12-1

$1970 \pm 50$

Carbon from disturbed summit of Structure 3C-14. Disturbance is ancient; deposit was sealed under more than $1 \mathrm{~m}$ flood silts and later cultural materials. Comments: CRD-1 $\sigma: 35$ BC to AD 55; (RJS): est date, 6th century AD. 
Carbon from Structure 3C-14, outwash of use or abandonment debris/ collapse, sealed by flood silts and later cultural deposits. Comments: CRDlo: AD 175 to 220; (RJS): est date, 6th century AD.

\section{P-3102. Sample 19R/47}

$1910 \pm 60$

Carbon on earlier floor assoc with Structure 3C-14, sealed by later Hoor and postabandonment deposits. Comments: Stuiver corrected: AD 5 to 205; (RJS): est date, ca An 500, probably equivalent to P-3105 (below).

\section{P-3105. Sample 19R/48}

$2660 \pm 190 *$

Carbon on earlier floor assoc with Structure 3C-14, sealed by later floor and postabandonment deposits. Comments: CRI)-10: 1095 to 590 вс; (RJS): est date, ca AD 500.

\section{P-3106. Sample 18F/1}

$1540 \pm 210^{*}$

Charred wood from NNE of site-core (ditch En), from presumed occupation layer assoc with Structure 2 of Loc 141. Comments: Stuiver corrected: AD 255 to 660; (RJS): est date, 8th century AD.

\section{P.3108. Las Quebradas, Sample 24C/14-1}

$1640 \pm 50$

Charcoal from Las Quebradas, Dept Izabal $\left(15^{\circ} 24^{\prime} \mathrm{N}, 88^{\circ} 46^{\prime} \mathrm{W}\right)$. Sample sealed by construction of $W$ side of Structure 1. Subm by Robert J Sharer, Univ Mus. Comments: Stuiver corrected: AD 340 to 530; (RJS): Classic Maya site. Est date, ca 7 th to 9 th century AD.

\section{P-3062. Cenote, Peten, Sample T2A/6 $1920 \pm 40$}

Carbonized wood fragments from Cenote, Dept Peten $\left(16^{\circ} 80^{\prime} \mathrm{N}, 89^{\circ}\right.$ $\left.57^{\prime} \mathrm{E}\right)$. Sample sealed by floor of Strata T4-2nd, 1.9 to $1.95 \mathrm{~m}$ below ground surface (Chase, 1979; 1983). Coll 1971 by Miguel Orrego and subm 1980 by A F Chase, Univ Mus. Sample id as Pinus sp, white pine group, by R B Miller, Forest Prod Lab, US Dept Agric, Madison, Wisconsin. Comments: $\mathrm{NaOH}$ pretreatment, CRD-1 $\sigma: 5$ BC to AD 75; (AFG): Lowland Maya early Late Classic, ca 500 to $700 \mathrm{AD}$.

\section{P.3208. Sakajut, Alta Verapaz}

$2880 \pm 190 *$

Carbon from Sakajut, Alta Verapaz $\left(15^{\circ} 25^{\prime} \mathrm{N}, 90^{\circ} 20^{\prime} \mathrm{E}\right)$, small earthen mound of Preclassic date (Sedat \& Sharer, 1972). Sample from interface of Feature 3 (occupation layer) and construction fill (Strata 3). Coll 1971 by D W Sedat and subm 1980 by R J Sharer. Comments: CRD10: 1385 to $815 \mathrm{BC}$; (RJS): few Preclassic sites are known from region and claims are often made of little or no occupation in region during this period. Sample should date to earliest occupation/construction of site, Early-Middle Preclassic, 900 to 400 BC.

\section{Chile}

\section{South America}

\section{P-2702. Quebrada da Los Conchas, Sample 4}

Quebrada da Los Conchas is shell heap $9 \mathrm{~km}$ to $\mathrm{N}$ of Antofagasta, $2^{\mathrm{a}}$ 
Region (23 $\left.30^{\prime} 3^{\prime \prime} \mathrm{S}, 70^{\circ} 31^{\prime} 7^{\prime \prime} \mathrm{W}\right)$. Coll and subm by Augustin Llagostera-Martinez, Mus Regional, Univ Norte, Sede Antofagasta. Charcoal from Layer 1, depth $40 \mathrm{~cm}$ (Wassén \& Bondeson, 1979/80; LlagosteraMartinez, 1979). Comments: $\mathrm{NaOH}$ pretreatment; (ALM): hearth at base of human occupation layer.

P-2588. Abtao-5, Sample 1

$$
\mathbf{2 3 0 0} \pm \mathbf{5 0}
$$

Abtao-5 is shell heap $18 \mathrm{~km}$ from Quebrada da Los Conchas, on S side of Mejillones Peninsula, Prov Antofagasta, 2a Region (23 $30^{\prime} 3^{\prime \prime} \mathrm{S}, 70^{\circ}$ $\left.31^{\prime} 7^{\prime \prime} \mathrm{W}\right)$. Coll and subm 1977 by Augustin Llagostera-Martinez (1979). Charcoal and soil from Layer $10 \mathrm{C}$, depth, $205 \mathrm{~cm}$. Comments: CRD-1\%: 420 to $380 \mathrm{BC}$; (ALM): debris from hearth.

\section{P-2587. Punta Blanco, Sample 2}

$1720 \pm 50$

Punta Blanco, area of shell heaps assoc with cemeteries, is $10 \mathrm{~km} \mathrm{~S}$ of Tocopilla, Prov Antofagasta, $2^{a}$ Region (22 $\left.2^{\circ} 10^{\prime} \mathrm{S}, 70^{\circ} 15^{\prime} \mathrm{N}\right)$. Coll and subm 1977 by Augustin Llagostera-Martinez (1979). Charcoal from Layer 15, depth, 65cm. Comment: CRD-1 $\sigma$ : AD 220 to 405.

\section{Santorini Island series}

GFOLOGIC SAMPLFS

\section{Greece}

Charred wood from Santorini I. from two loci, Millo region of Therasia $\left(36^{\circ} 26^{\prime} \mathrm{N}, 24^{\circ} 21^{\prime} \mathrm{E}\right)$ and Akrotiri, Thera, near caldera rim $\left(36^{\circ} 21^{\prime} \mathrm{N}, 24^{\circ} 26^{\prime} \mathrm{E}\right)$. Coll 1978 by W L Friedrich, Aarhus Univ, Aarhus, Denmark, and H Pichler, and subm 1979 by P P Betancourt, Univ Pennsylvania.

General Comment: represents so-called Akrotiri/Millo palaeosol at base of characteristic ignimbrite layer (Friedrich, Pichler, \& Kussmaul, 1977).

P-3128. Sample IV, V, VIII

$16,090 \pm 920 *$

Charred wood from Milo region, Therasia, Akrotiri/Millo palaeosol, ca $20 \mathrm{~cm}$ below ignimbrite.

P-3131. Sample XI

Charred wood with ignimbrite from Akrotiri region, Millo palaeosol.

P-3129. Samples VII, IXa, IXb

$>\mathbf{3 8 , 9 0 0}$

Charred wood from Akrotiri region, Millo palaeosol, $5 \mathrm{~m}$ below Upper Pumice series (Bo).

\section{United States}

\section{P-2970. Dutchess Quarry Cave \#8, Samples $\quad 7270 \pm 410 *$ 6 and $7 \quad \delta^{13} \mathrm{C}=-24.5 \pm 0.1 \%$}

Dutchess Quarry Cave \#8, Florida, Orange Co, New York (358 $41^{\prime}$ $\mathrm{N}, 36^{\circ} 74^{\prime} \mathrm{W}$ ) is from Paleo-Indian period (Guilday, 1969; Funk et al, 1969). Charcoal mixed with calcite from bottom of Breccia 1, Unit B, depth, 2.3 to $2.4 \mathrm{~m}$. Coll and subm by J S Kopper, Dept Sociol \& Anthro- 
pol, Long Island Univ, Greenvale, New York. Comment (JSK): directly assoc with two "Clovis" type fluted points and caribou bone (Rangifer sp). Artifacts, food debris, and utilized cobbles indicate area was not living floor but occasional occupation site. Breccia probably deposited during warm, wet period-Two Creeks interstadial, ca 12,500 BP, or between Chocrane and Valders readvances, ca 10,000 BP.

\section{REFERENCES}

Ashmore, W and Sharer, R J, 1978, Excavations at Quiriqua, Guatemala: The ascent of an elite Maya center: Archaeology, v 31, p 10-19.

Bayard, D T, 1980, The Pa Mong archaeological survey programme, 1973-1975: Studies in Prehistoric Anthropol 13, Univ Otago, Dunedin, New Zealand.

Chase, A F, 1979, Regional development in the Tayasal-Paxcaman zone, El Peten, Guatemala: a preliminary statement: Ceramica Cultura Maya, v 11, p 86-119.

$1983(\mathrm{~ms})$, A contextual consideration of the Tayasal-Paxcaman zone, El Peten, Guatemala: PhI dissert, Dept Anthropol, Univ Pennsylvania. in press, Archaeology in the Maya heartland: the Tayasal-Paxcaman zone, El Peten, Guatemala: Archaeology, in press.

Chase, D Z, 1982a (ms), Spatial and temporal variability in post classic northern Belize: PhD dissert, Dept Anthropol, Univ Pennsylvania.

1982b. The Ikilik ceramic complex at Nohmul, northern Belize: Ceramica Cultura Maya, v 12, p 71-81.

Chase, $\mathrm{D} \mathrm{Z}$ and Chase, A F, 1982, Yucatec influence in terminal classic northern Belize: Am Antiquity, v 47, no. 3, p 596-614.

Dolukhanov, P M, 1979, Paleogeography and prehistoric settlement in Caucasus and central Asia during the Pleistocene and Holocene: Atti Inst Univ Orientale, Napoli, p 1-26.

Dyson, $\mathrm{R} \mathrm{H}, \mathrm{Jr}$ and Howard, $\mathrm{S} \mathrm{M}$, eds, in press, Preliminary report of the Tappeh Hesar restudy project, 1976: Mesopotamia.

Fishman, Bernard, Forbes, Hamish, and Lawn, Barbara, 1977, University of Pennsylvania radiocarbon dates XIX: Radiocarbon, v 19, p 188-228.

Fishman, Bernard and Lawn, Barbara, 1978, University of Pennsylvania radiocarbon dates XX: Radiocarbon, v 20, p 210-233.

Friedrich, W L, Pichler, H, and Kussmaul, S, 1977, Quaternary pyroclastics from Santorini, Greece and their significance for the Mediterranean palaeoclimate: Geol Soc Denmark Bull, v 26, p 27-39.

Funk, R, Walters, G R, Ehlers, W F, Guilday, J E, and Connally, G G, 1969, The archaeology of Dutchess Quarry cave, Orange County, NY: Pennsylvania Archaeologist, v 39, p 7-22.

Gorman, C F and Charoenwongsa, Pisit, 1976, Ban Chiang: a mosaic of impressions from the first two years: Expedition, $v$ 18, no. 4, p 14-26.

Guilday, J E, 1969, A possible caribou cave, Orange County, NY: New York Archaeol Assoc Bull, v 45, p 24-29.

Khlopin, I N, 1977, Les tombes de Sumbar-une clef pour l'harmonisation des chronologies des sites de l'époque du bronze du sud de l'Asie centrale et de l'Iran: Le plateau Iranian et l'Asie centrale des origines a la conquête islamique, Paris, p 143154.

Klein, Jeffrey, Lerman, J C, Damon, P E, and Ralph, E K, 1982, Calibration of radiocarbon dates: tables based on the consensus data of the Workshop on Calibrating the Radiocarbon Time Scale: Radiocarbon, v 24, p 103-150.

Llagostera-Martinez, Augustín, 1979, 9,700 years of maritime subsistence on the Pacific: An analysis by means of bioindicators in the north of Chile: Am Antiquity, v 44, no. 2, p 309-324.

McGovern, P E, 1979, The Baq'ah Valley, Jordan: A cesium magnetometer survey: MASCA Jour, v 1, no. 2, p 39-41.

1980, Explorations in the Umm ad-Dananir regions of the Baq'ah valley, 1977-1978: Annual Dept Antiquities of Jordan, v 24, p 55-67.

1981a, Baq'ah Valley project 1980: Biblical Archaeologist, v 44, p 126-128.

1981b, The Baq'ah Valley, Jordan: T Test soundings of cesium magnetometer anomalies: MASCA Jour, v 1, no. 7, p 214-217.

1982, Exploring the burial caves of the Baq'ah Valley in Jordan: Archaeology, v $35, \mathrm{p}$ 46-57. 
McGovern, P E, Harbottle, G, and Wnuk, C, 1982, Late Bronze age pottery fabrics from the Baq'ah Valley, Jordan: composition and origins: MASCA Jour, v 2, no. 1, p 8-12.

McGovern, P E, Piggott, V, and Notis, M, 1982, Early Iron age steel from the Baq'ah Valley, Jordan: MASCA Jour, v 2, no. 2, p 35-39.

Okladnikov, A P, 1956, Drevneishie arkheologicheskie pamyatniki krasnovodskogo polvostrova: Trudy Yutake, v 7, Ashkhabad.

Penny, J S, Jr, 1982 (ms), Petchabun peidmont survey: an initial investigation of the prehistory of the western margins of the Khorat Plateau, Northeast Thailand: PhD dissert, Dept Anthropol, Univ Pennsylvania.

Pritchard, J B, 1975, Sarepta: A preliminary report on the Iron age excavations of the University of Pennsylvania, 1970-1972: Univ Mus Monographs, Univ Pennsylvania, $114 \mathrm{p}$.

Redford, D B, 1977, Preliminary report of the first season of excavations in east Karnak, 1975-76: Jour Am Research Center Egypt, v 14, p 9-32.

1978, The razed temple of Akhenaten: Scientific Am, v 239, p 136-147

1979, The Akhenaten temple project and Karnak excavations: Expedition, v 21, p 54-59.

Rutter, J B and Rutter, S H, 1976, The transition to Mycenaean: A stratified middle Helladic II to late Helladic IIA pottery sequence from Ayios Stephanos in Lakonia: Inst Archaeol, Univ California, 71 p.

Schauffler, William, 1976, Archaeological survey of Ban Chiang culture sites in Northeast Thailand: Expedition, v 18, no. 4, p 27-37.

Schmidt, E F, 1933, The Tepe Hissar excavations: Mus Jour Philadelphia, v XXIII, no. 4 , p 323-483.

1937, Excavations at Tepe Hissar, Damghan: Univ Mus, Philadelphia, 478 p.

Sedat, D W and Sharer, R J, 1972, Archaeological investigations in the northern Maya Highlands: New data on the Maya preclassic: Contr Univ California Archaeol Research Facility, v 16, p 23-35.

Sharer, R J, 1978, Archaeology and history at Quirigua, Guatemala: Jour Field Archaeol, v $5, \mathrm{p} 51-70$.

Sharer, R J and Ashmore, Wendy, eds, 1979, Quirigua reports, Vol I: Univ Mus Monographs No. 37, Univ Pennsylvania, 73 p.

Sidrys, R, 1976 (ms), Mesoamerica: An archaeological analysis of a low-energy civilization: PhD dissert, Univ California, Los Angeles.

Stuiver, Minze, 1982, A high-precision calibration of the AD radiocarbon time scale: Radiocarbon, v 24, p 1-26.

Taylour, Lord William, 1972, Excavations at Ayios Stephanos: British School at Athens Ann, v 67, p 205-270.

Todd, I A, 1978, Excavations at Kalavasos-Tenta, Cyprus: Archaeology, v 31, p 58-59.

1982a, Radiocarbon dates for Kalavasos-Tenta and Kalavasos-Ayios: Rept Dept Antiquities, Cyprus, 1982, p 8-11.

1982b, Vasilikos valley project: Fourth preliminary report: Jour Field Archaeol, v 9, p 35-77.

Wachsmann, S and Raveh, K, 1981, An underwater salvage excavation near Kibbutz haHotrim, Israel: Internatl Jour Nautical Archaeol Underwater Exploration, v 10, p 160.

Wassén, S H and Bondenson, W E, 1979/80, Archaeological notes and botanical research on endocarps from Quebrada Las Conchas, Antofagasta, Chile: Särtryck Göteborgs Etnog Mus Årstryck 1979/80, p 59-71.

White, Joyce C, 1982, Ban Chiang: Discovery of a lost Bronze age: Univ Mus, Univ Pennsylvania and Smithsonian Inst, Washington, DC, 96 p. 